\title{
VIEWS OF INDONESIAN STUDENTS ON TRANSLATION THEORY CLASS: A CASE STUDY
}

\author{
Suwarni Wijaya Halim \\ suwarni@bundamulia.ac.id \\ Universitas Bunda Mulia
}

\begin{abstract}
In any practical field, tensions always exist between the group that views theoretical study as necessary and those who consider it pointless: likewise in the case of translation. Translation often places most of its emphasis on its practical aspects. The theoretical aspect of translation is often marginalized in professional settings. Nevertheless, in the context of translator training, translation theory is as an essential area, which needs to be studied and explored. This study investigated the views of 5th- and 7th-semester students of English Department at a private undergraduate educational institution in Jakarta, Indonesia, on translation theory. The class Theory of Translation is the only official locus for instruction in theories of translation at the target institution. The results of this study may provide several benefits, including the aiding the creation of syllabuses for and teaching translation theory. The author used a questionnaire to acquire the data needed to address the research questions. The results of this research revealed that most students in the 5th and 7th semester of English study in Jakarta, Indonesia, have a positive perception of translation theory, believing that it is essential for translation practice. Moreover, they also considered that translation theory could provide solutions for issues in the practice of translation.
\end{abstract}

Keywords: translation theory, student views, case study

\section{INTRODUCTION}

Translation is often considered a simply practical field that places most of its emphasis on its practical aspects. After all, translation has probably been a livelihood since the second language arose. The same cannot be stated for the translation theory. Translation studies is the field that focuses on the activities and results of translation, as well as other phenomena related to translation, and it only emerged several decades ago. While this does imply that this field of study is relatively young, does it also mean that the theoretical aspect of translation is inferior to its practical aspect?

Baker (1992, pp. 1-2) found that the study of theory is necessary for encouraging student and novice translators to "reflect on what they do, how they do it, and why they do it one way rather than another." After such study, they will be better equipped to deal with real challenges in translation during their careers. Gile (2010, p. 256) concluded that in the theoretical study and discussion of translation theories, problems, and procedures in translation classroom, students would become more confident in confronting and prepared to tackle issues of translation and to make decisions during translation. This sentiment is also conveyed by translator trainers and instructors who consider it easier to teach the cognitive aspects and finer points of translation through examination of translation theory.

However, some practitioners believe that translation theory does not provide any real benefit for translation practice. According to Shuttleworth (2001, p. 498), "many professional translators argue vehemently that translation theory-and 
even any kind of formal training - is a waste of time." They claim that translation theory does not assist them when they are translating. Thus, they perceive translation theory to be less important than the real practice of translation.

To summarize, conflicting points of view on the significance of translation theory for translation activity exist in the literature. Many translators believe that translation skills can only be honed through the continuous practice of translating. They do not consider any theoretical aspects of translation or the possibility that they might assist them to translate. Pym noted that translators who do not formally study translation might "work faster and more efficiently because they know less about complex theories" and it might be that they "have fewer doubts and do not waste time reflecting the obvious" (2010, p. 4).

Those skeptical of the importance of translation theory are mostly professional translators. Some of them claim that they themselves did not benefit from the study of the theoretical aspects of translation (Shuttleworth, 2001, p. 498). Chesterman and Wagner (2002, p. 1) also quoted several professional translators who expressed their discontent with existing translation theories.

What is the reason for this discontent? According to Gile (2010, p. 252), there is a gap between translation theory and translation practice. Two central issues appear regarding this gap, per Gile (2010), namely, relevance and effectiveness. Many professional translators believe that translation theory is irrelevant to them and not in line with their needs (Gile 2010, p. 252). They claim that existing theories do not help solve the problems that they often encounter as they translate. For example, a significantly higher number of empirical studies of literary translation exist than studies of legal translation, although the demand for legal translation is much higher than for literary translation. In other words, existing translation theory cannot meet and accommodate the needs of the translators. Many professional translators think that translation theory only offers abstract concepts and paradigms that are not directly usable or applicable to real translation. Furthermore, the solutions proposed by translation theory to resolve translation problems cannot be implemented in most cases.

However, there is also a group that believes that translation theory can offer something more. This group is composed of translator trainers and students. These individuals consider that studying translation theory can assist the real process of translation. Using translation theory, translator trainers can explain and describe complexities of the translation process to students, and translator students can understand and prepare themselves to face the complexity of translation process. It is especially useful for boosting students' creative and critical thinking when they encounter problems in translation and challenges to their selfesteem regarding translation decisions.

What is behind these opinions? Some experts believe that translation theory provides a reflection of real translation problems that the translators often face, and it proposes a range of different solutions, formulated by experts. Translation theory also specifies technical details of the real translation process and the skills beyond linguistic ones that the translators need to be proficient in, such as research skills, recognition of crosscultural references, and so on. Translator trainers can use this information to design their curricula and syllabuses, and translator students can use the information given to improve and develop their translation competences.

In summary, as noted above, two opposed opinions exist: one side places the full emphasis on translation practice and none on translation theory, and the other side believes that translation theory and practice should be studied in a balanced manner. 
Many experts in translator training believe that translation theory could bring many benefits for translator students (Baker, 1992; El-Shiyab, 1996; Chesterman \& Wagner, 2002; Bartrina, 2005; Pérez, 2005; Gile, 2010). In addition to training critical and creative thinking and increasing self-confidence, study of translation theory could increase the awareness of methodology among the translator students (Bartrina, 2005, p. 178). Furthermore, translation theory can be used to justify certain decisions made while translating (Pym, 2014).

Moreover, according to PACTE Group (2003, 2005), to enhance translation competence, a range of elements must be considered; one of these is translation subcompetence. Translation sub-competence includes "knowledge about how translation functions: types of translation units, process required, methods and procedures used (strategies and techniques), and types of problems" (PACTE Group, 2003, p. 59) and "knowledge of the principles that guide translation (processes, methods and procedures, etc.) and the profession (types of translation briefs, users, etc.)" (PACTE Group, 2005, p. 610). This knowledge is discussed and elaborated extensively and in a detailed manner in the body of work that constitutes translation theory. Knowledge of translation sub-competence can lead to the development of strategic sub-competence, which involves the analysis of translation problems and the implementation of proper and creative solutions for dealing with such problems (PACTE Group, 2005).

As an educator and professional translator, the author believed that translation theory can offer many benefits for students. Are student translators of the same mind? This is important because students translators are one of the stakeholders in translator training. Also, the students' perceptions of different subjects may promote or inhibit students' progress in mastering the subject. Thus, it is imperative to consider their needs, expectations, aspirations, and suggestions in the composition of the curricula, syllabuses, and lesson plans.

A translation major is offered in the English department at the author's place of employment. Students of English can choose to follow this branch from the 6th semester. During the 5th semester, students are required to take the class Theory of Translation, which is the only translation class that offers an introduction to the theoretical aspect of translation. The author investigated the views of the students of English department, specifically 5th-semester students, who were, during the initial part of this study participating in the Theory of Translation class, and 7th-semester students who had already completed the theory and translation class and were participating in other practical translation classes.

This topic has previously been studied by Ordóñez-López and Agost (2014) and Agost and Ordóñez-López (2015), who conducted empirical study in universities in Spain on whether attitudinal differences toward the practice of translation and Theory of Translation would affect students' perceptions and impede or enhance their learning. Ordóñez-López and Agost (2014) examined 928 undergraduate and graduate students. The researchers administered a questionnaire in the form of closed-ended, multiple choice, and open-ended questions. Their results show that the students believed that translation theory was important and useful and believed that translation theory made a contribution to their training. The students also preferred for translation subjects to be compulsory instead of optional and to have few credits (OrdóñezLópez \& Agost, 2014, p. 338). The second study by Agost and Ordóñez-López (2015) explored more deeply by examining myths and prejudices among the students toward the subject of translation theory. The 
design and instruments for the research were similar to the previous study. The participants were 916 undergraduate and graduate students from different universities in Spain. In the result, the students considered that the theory and practice of translation are equally important. Furthermore, it was found that the students had a positive attitude toward and perception of translation theory, which was contradictory to the hypothesis.

This author replicated both studies in a new context to investigate the views of 5th- and 7th-semester students in an English department at one private university in Jakarta, Indonesia, on translation theory to determine their perceptions of translation theory. It is largely unknown whether the student translators had positive or negative perceptions of translation theory. The research question was "How do the Indonesian student translators perceive the translation theory subject?"

The study was expected to produce results that could benefit those designing and improving the curriculum, syllabus, topics, and materials of such classes. Furthermore, it is hoped that this study will benefit lecturers who teach translation.

\section{RESEARCH METHOD}

This study was qualitative in nature. To address the formulated research question, the author administered a questionnaire to Indonesian student translators, specifically 5th- and 7thsemester students in the English department of a private university in Jakarta, Indonesia. The questionnaire featured a combination of open-ended and closed-ended questions. The responses to the closed-ended questions were calculated as percentages, whereas the answers to the open-ended questions were analyzed using content analysis. Numerical data were used in this research, but the calculations were very simple, and the students' qualitative responses were considered more important. Thus, the study was characterized as qualitative.

The author utilized case study as the research design. According to Dörnyei (2007, p. 152), a case study is "not a specific technique but rather a method of collecting and organizing data so as to maximize our understanding of the unitary character of the social being or object studied." Because this study only focused on two particular groups as its subjects, it was considered that a case study design would be appropriate for this research.

The participants were 49 5th- and 7thsemester students in the English department of one private university in Jakarta, Indonesia. These groups of respondents were chosen because they either were taking or had taken in the Theory of Translation class, the only course in the department that centers on the theoretical aspects of translation activity.

As noted above, the students of English department could only take Theory of Translation during their 5th semester. During the initial part of this study, the 5th-semester students were taking in Theory of Translation. The 7thsemester students had already taken it and were taking other practical translation classes. To ensure the validity and the objectivity of the analysis, the author protected the anonymity and confidentiality of the students. Before starting the research, the author obtained the consent of the head of the department and, independently, of the students. The students were informed that their identities would be treated confidentially, and their responses would be anonymous.

An online questionnaire was used to gather data. It was adapted from OrdóñezLópez and Agost (2014). This questionnaire had open-ended and closedended questions. The close-ended parts were accompanied by a limited list of possible answers, from which the students chose. Then, the students were asked to 
account for their choices in the open-ended parts. The questionnaire was administered toward the end of the semester, and the answers acquired were used as the data for this research.

Then, the data were analyzed using a simple percentage calculation (for the closed-ended questions) and content analysis (for the open-ended questions). According to Tipaldo (cited in Bertinetti and Gardenal, 2016, p. 213), content analysis allows the author to categorize qualitative data in a detailed manner and draw inferences or conclusions from those data. Content analysis was used to analyze qualitative data. Qualitative content analysis is defined as "a research method for the subjective interpretation of the content of text data through the systematic classification process of coding and identifying themes or pattern" (Hsieh \& Shannon, 2005, p. 1278). In other words, content analysis involves creating codes from the qualitative data and categorizing the codes into themes.

After the author acquired the data, the answers for the closed-ended questions and open-ended-questions were placed into separate files. The answers for the closed-ended questions were calculated and analyzed, and the answers for the open-ended questions were scrutinized, summarized, and explained.

\section{FINDINGS AND DISCUSSION}

\section{Question 1}

The first question on the questionnaire was "How do you view theoretical training in translators' education?" The four available answers were Indifferent, Unnecessary, Advisable and Essential. All 49 students answered this question, and Table 1 gives a summary of their answers.

The students generally showed a favorable view of theoretical training in translators' education. Most believed that theoretical training is important, or at least recommended, for training future translators.

Table 1. Summary of Responses to Question 1

\begin{tabular}{lll}
\hline Answers & $\begin{array}{l}\text { Number of } \\
\text { Responses }\end{array}$ & Percentage \\
\hline Essential & 34 & $69.39 \%$ \\
Advisable & 13 & $26.53 \%$ \\
Unnecessary & 1 & $2.04 \%$ \\
Indifferent & 1 & $2.04 \%$ \\
Total & 49 & $100 \%$ \\
\hline
\end{tabular}

The students generally perceived theoretical training as a foundation or necessity that is required to be mastered before more difficult subjects, specifically certain practical lessons. They considered theoretical training to be a preparatory step to be taken before going deeply into translation study.

The students also stated that theoretical training was the basic requirement, and most claimed that theories of translation would guide them as they translated. The responses below indicate their views.

"I think it's essential because, as a student, to understand the material, especially on translation, we must study the theory before we can learn the procedure for translating something. However, if we don't know the theory first, it will be difficult to understand and do assignments. Theory can function as a guide to doing assignments or translations."

"[It is] because the theories are basic needs for those who major in translation, and without them, students [who choose translation] will most likely become lost in future translation courses."

"While translation does focus on the practical, translation needs theoretical training for the basic concept of being 
able to create a proper translation that is understandable by readers."

Some students wrote that theoretical training is essential or advisable in translator training because it provides knowledge and solutions for cases where certain challenges and difficulties are being faced in translation. The students concluded that they could turn to translation theories when they faced obstacles while translating.

"[Theory] is essential for translation students because it will help us translate using the methods and strategies created by experts."

"[Theory] reminds us not to translate everything [literally], that there are [many] ways to translate texts."

"1) We might need it to conduct research or write a thesis. 2) We might need the theories to address obstacles during translation."

Interestingly, one student answered "indifferent." The student stated that this opinion was based on the position that practice is as important as theoretical training. Furthermore, one student answered "unnecessary" because of the belief that "theory is not that helpful because translation [is] about practice."

The finding for this question is in line with the results of Ordóñez-López and Agost (2014). In their study, 34.3 percent of respondents believed that theoretical training is "essential," and 48.8 percent considered that it is "advisable." Only 2.6 percent believed that theoretical training is unnecessary.

In short, most students perceived theoretical training in a positive light. This group believed that theoretical training is important, as a basic and foundational skill in translating and as a source of solutions for problems and challenges in translation.

\section{Question 2}

The second question inquired whether the students preferred translation theory to be compulsory or optional. Table 2 gives the results.

Table 2. Summary of Responses to Question 2

\begin{tabular}{llc}
\hline Answers & $\begin{array}{l}\text { Number of } \\
\text { Responses }\end{array}$ & Percentage \\
\hline $\begin{array}{l}\text { Translation theory } \\
\text { subject as compulsory } \\
\text { subject }\end{array}$ & 37 & $75.51 \%$ \\
$\begin{array}{l}\text { Translation theory } \\
\text { subject as optional } \\
\text { subject }\end{array}$ & 12 & $24.49 \%$ \\
Total & 49 & $100 \%$ \\
\hline
\end{tabular}

This result indicates that most students considered that translation theory should be compulsory and not optional. This result is related to the result for Question 1 , which determines students' views on the importance of theoretical training. Some students believed that translation theory should be compulsory because they considered it essential for training. The students elaborated on how translation theory subject is the foundation of translation itself, how it can help resolve problems in translation, and how it can guide them as they translate. Below are responses from some students who preferred translation theory subject to be compulsory subject.

"[It is] because, as I said [in the previous question], translation theory is a guide for the student to know, understand, and complete assignments. So, it's really important to make translation theory compulsory."

"As in my answer from number 1, theory is important. If studying it is optional, then some students might not take it at all. If it is mandatory, then all of the students will have to take it, whether they want to or not."

"If we [get] stuck when translating text, we can use the methods and strategies provided in the translation theory class." 
Other students thought that translation theory should be compulsory because students in the English department should be able to translate texts or at least know the basics of translation. Below are some responses indicating this view.

"In daily life, English literature students should be able to translate text. In my opinion, translation theory should be compulsory because students need to be able to understand the meaning of texts."

"[It is] because we, as students of the English language and culture must understand translation."

"As a student of the English language and culture student, I must at least know about the Theory of Translation."

Other students expressed their belief that translation theory should be compulsory because translation theory may be an excellent introduction for those interested in the translation major. The current curriculum of the English department notes two majors that students can choose from, once they are in their 6th semester: the teaching major or the translation major. The students are taught basic English knowledge, communication, and grammatical and linguistic skills in the 1 st to 5th semesters, and students in the 6th to 8th semesters learn skills and knowledge related to their specific area of interest; in this case, this may be either teaching or translation.

The Theory of Translation class is currently taught to students in the 5th semester, and it is compulsory for all students in that semester. Some considered that because it was compulsory, those taking it would have at least a general idea of the translation major, particularly for those who are considering joining the translation major. Such responses are given below.

"If it is a compulsory subject, all students will get basic knowledge of translation and could decide whether they want to take translation or not. Even if they don't, they will still have at least a little bit of knowledge about it."

"The subject should be compulsory because translation is a major in the English department, so having translation theory as a compulsory subject would be very helpful for those who major in translation."

"[It is] because we need an idea about translation before we choose our majors."

There were also students who responded that translation theory should be optional and not compulsory. Most stated that not all students were interested in majoring in translation, and not all students who were majoring in translation would want to study translation theories. Therefore, the subject should not be compulsory but optional, to give students more freedom to choose. Below are some such responses.

"[It is] because not everyone wants to become a translator. These students might not give their strongest effort or may feel inconvenienced by the class. It would be better if translation theory was optional. That way, those who don't want to become a translator don't have to take the class."

"[It should be optional] because I think some students might think consider it a burden for them because they don't like translation." 
"I suggest that it should be optional because I think student who are planning to take teaching classes will not [consider] this course useful for them because they are not going to translate."

However, two students believed that the subject should be optional for other reasons, namely they claimed that other practical subjects be prioritized as compulsory. For instance, practicing translation is more vital than learning theories. Below are their responses.

"Drilling technique is more important."

"Practical subjects should be the compulsory ones."

This finding is also in accordance with those of Ordóñez-López and Agost (2014). Most of their subjects also believed that translation theory subject should be made a core subject (43.6 per cent) or compulsory (34.1 per cent).

In brief, most students thought that translation theory has great importance for the area of translator training. This is reflected in most answers from students in this study, that they would prefer the subject be compulsory, not optional. Other reasons include the expectations on English department students and the role of translation theory as an introductory course for students who are interested in a translation major.

\section{Question 3}

The third question was "Ideally, how many credits (SKS) should the translation theory subject be?" Four options were given for the students: 2 credits, 4 credits, 6 credits, and 8 credits. Currently, Theory of Translation is only 2 credits. Opinions from 7th semester students, who had already completed the class, and the 5th semester students, who were currently taking it, were expected to yield valuable insights. Table 3 summarizes the responses.

Table 3. Summary of Responses to Question 3

\begin{tabular}{lll}
\hline Answers & $\begin{array}{l}\text { Number of } \\
\text { Responses }\end{array}$ & Percentage \\
\hline 2 credits & 24 & $48.98 \%$ \\
4 credits & 23 & $46.94 \%$ \\
6 credits & 1 & $2.04 \%$ \\
8 credits & 1 & $2.04 \%$ \\
Total & 49 & $100 \%$ \\
\hline
\end{tabular}

It was found that the number of students who believed that the current level of credits for Theory of Translation ( 2 credits) should be maintained was almost equal to the number of those who thought that the number should be 4 . Only a few students believed that more than 4 credits was needed.

Most students who answered "2 credits" explained that 2 credits were enough because the scope of the subject was small, only discussing the basic theoretical aspects of translation. Because the subject does not include any practical training, they stated that 2 credits were sufficient to review the basic translation theories. Below are responses supporting this position.

"It would not be effective if the course had more credits because only to know about the basic Theory of Translation."

"If the class is only theory, I suggest it should be 2 credits, but if exercises are involved, I suggest that it should be 4 credits".

"2 [credits] is good enough for students because we just learn the basics of translation."

However, one student believed that the subject should be worth 2 credits because students might become bored if the number of credits was larger and if they were studying too much theory. This student posited "because it is theoretical, I think it would be better if it was just 2 credits, considering that the students might get bored if it is more." 
The students who answered "4 credits" generally believed that 2 credits would be too brief because there are many more complex theories that can be discussed, and more credits would result in the students obtaining greater opportunity to comprehend translation theories. Excerpts of the responses given by the students that indicate such sentiment are given below.

"[It is] because 2 credits seem too short for a theoretical class and 6 and 8 credits are kind of impossible [because] the students will only get bored for that many credits. 4 credits seems ideal".

"Because this is about theory, I think that 4 credits are needed for this subject because there are so many theories on translation and we need more time to understand it".

"[It is] because there are a lot of theories that students need to know, and to study all of them, 2 credits isn't enough, I think."

Another student had a similar thought. That student suggested 6 credits for the class because it is "to help the students understand the material better, so the teacher won't have to deal with the limited time, and have the students understand the theory clearly." One student responded 8 credits. However, the explanation for this response was considered irrelevant to the context.

This result agrees with the findings of Ordóñez-López and Agost (2014). In their questionnaire, the lowest number of credits they provided was "up to 6 credits," whereas the highest number of credits was "more than 12". Most of their respondents chose "up to 6 credits", which was the smallest option among others. Similarly, in this study, the smallest option with the lowest number of credits ( 2 credits) had the largest response. However, here, the number of students choosing " 2 credits" and " 4 credits" was almost the same.

The quantitative results of the questionnaire indicate that, even though there were more respondents who considered that " 2 credits" would be the ideal commitment for Theory of Translation (24 students), there was also high demand for a larger number of credits (4 credits with 23 students), and this finding cannot be altogether dismissed altogether. The qualitative results show that both groups who chose " 2 credits" and "4 credits" believed that translation theories are important. However, those who chose "2 credits" emphasized the study of basic theories in translation, whereas those who chose "4 credits" emphasized the study of complex theories.

\section{Question 4}

Question 4 is "What do you think about the degree of usefulness of theoretical training in translators" education?" The students were asked to choose one out of four available options: Essential, Quite Useful, Not Very Useful, and Not Useful. The result can be seen in Table 4.

Table 4. Summary of Responses to Question 3

\begin{tabular}{lll}
\hline Answers & $\begin{array}{l}\text { Number of } \\
\text { Responses }\end{array}$ & Percentage \\
\hline Not useful & 0 & $0.00 \%$ \\
Not very useful & 2 & $4.08 \%$ \\
Quite useful & 19 & $38.78 \%$ \\
Essential & 28 & $57.14 \%$ \\
Total & 49 & $100 \%$ \\
\hline
\end{tabular}

In response to the question why they gave these answers, most students who answered "Essential" and "Quite useful" repeated their answers from Question 1 and 2. They believed that theoretical training would be helpful because it can be used as to guide navigation around the complexities of translation and as a basic 
skill in learning translation. Such responses follow.

"It is very useful for every beginner in the field as it might help learn about not only how to translate but also the history and methods of translation."

"It is useful because theories [are] basic lessons for understanding how to apply knowledge of the subject before doing an exercise."

"[It acts] as a guide for the translator or as a tool for the consideration of the translator consideration."

A few students also mentioned that theoretical training may be a great introduction for students who are interested in learning more about the translation major. They also consider that translation theory can give clearer idea of the real practice of translation. The below responses indicate such view.

"[It is] to accustom the translator to the real world of translation and to prepare them so that they [can] face the problems of translating with different ideas or in a different way."

"Again, theoretical training means being introduced to translation itself. So it is essential to know everything about it."

Two students, however, had a different opinion and answered that theoretical training is "Not very useful." One student stated that "practice is more important than theory". Therefore, this student did not have a positive response to the subject of translation theory. However, the other student believed that theoretical training is not very useful "because if you [want to] be a translator, you have to know the basics first." There was no further text after for this response; therefore, it is not known what basic skills the student was referring to.

This finding is in line with the results of Ordóñez-López and Agost (2014). In their study, 63.6 percent reported believing that theoretical training in translator education is either essential or quite useful. In addition, it was emphasized that none of the students answered, "Not useful," and only two students responded with "Not very useful," which means that the majority of the students believed that theoretical training is beneficial in some degree.

\section{CONCLUSION AND SUGGESTION}

\section{Conclusion}

A response was found to the research question, which addressed the student translators' perception of translation theory. Perceptions among the 5th and 7th semester students generally was theoretical training is something important and helpful to learn. This was also evident in the responses of most students in favor of translation theory subject as a compulsory subject. Those students believe that theoretical training can act as a guide in the process of translation, and they feel like that they can turn to theory for solutions when they face challenges in translation.

Regarding credits, opinions were more divided. The qualitative data indicate that the students who preferred a 2-credit course would like to focus on basic theory, whereas those who preferred 4-credit course wished to learn more about complex theories. Despite these differences, it is clear from the qualitative data that both groups of students still emphasized the importance of studying translation theory. However, the only difference between them was their focus and their expectations of the class.

This study produced findings that can be used by educational institutions as they devise curricula for a translation major. Because students believed translation 
theory to be an important subject, curriculum developers should consider including subjects that focus on translation theory. Furthermore, with knowledge of the perceptions and views of students on theoretical training in translation, syllabus makers, and lecturers can adjust their topics, materials, and styles in teaching translation theories.

\section{Suggestion}

It is important to note the limitations of this research. Because it was limited to one university and had a small number of participants, its results of the research cannot be generalized to all cases. Therefore, future researchers who would like to conduct a study on this topic may wish to consider broadening the scope from what was done here to include a larger number of participants and different institutions.

\section{REFERENCES}

\section{References coming from Journal:}

Agost, R., \& Ordóñez-López, P. (2015). Translation theory: Myths, prejudices and realities. Babel, 61(3), 361-380. doi:10.1075/babel.61.3.03ago

El-Shiyab, S. (1996). The importance of teaching translation theory. Babel, 42(3), 166-173. doi:10.1075/babel.42.3.05shi

Hsieh, H-F., \& Shannon, S. E. (2005). Three approaches to qualitative content analysis. Qualitative Health Research, 15(9), 1277-1288. doi:10.1177/1049732305276687

PACTE Group (2005). Investigating translation competence: Conceptual and methodological issues. Meta, $50(2)$, 609-619.
Pérez, M. C. (2005). Applying translation theory in teaching. New Voices in Translation, 1, 1-11.

Shuttleworth, M. (2001). The role of theory in translator training: Some observations about syllabus design. Meta, 46(3), 497-506. doi:10.7202/004139ar

\section{References coming from Book:}

Baker, M. (1992). In other words: A coursebook of translation. New York, NY: Routledge.

Bartrina, F. (2005). Theory and translator training. In M. Tennent (Ed.), Training for the new millennium: Pedagogies for translation and interpreting (pp. 177-189). Amsterdam: John Benjamins.

Bertinetti, G., \& Gardenal, G. (2016). Enterprise risk management and integrated reporting: Is there a synergism?. In C. Mio (Ed.), Integrated Reporting: A New Accounting Disclosure (pp. 205230). London: Palgrave Macmillan.

Chesterman, A., \& Wagner, E. (2002). Can theory help translators?: A dialogue between the ivory tower and the wordface. Manchester: St. Jerome Publishing.

Dörnyei, Z. (2007). Research methods in applied linguistics. Oxford: Oxford University Press.

Gile, D. (2010). Why translation studies matters: A pragmatist's viewpoint. In D. Gile, G. Hansen, \& N. K. Pokorn (Eds.), Why translation studies matters (pp. 251-261). Amsterdam: John Benjamins. doi:10.7202/011004ar 
Ordóñez-López, P., \& Agost, R. (2014). An empirical study of students' views on theoretical subjects: The role of theory in translation degrees at Spanish Universities. In Y. Cui \& W. Zhao (Eds.), Handbook of Research on Teaching Methods in Language Translation and Interpretation (pp. 324-345). Hershey, PA: Information Science Reference.

PACTE Group. (2003). Building a translation competence model. In F.
A. dos Santos (Ed.), Triangulating translation: Perspectives in processoriented research (pp. 43-66). Amsterdam: John Benjamins.

Pym, A. (2010). Exploring translation theories. New York, NY: Routledge.

Pym, A. (2014). Exploring translation theories (2nd Edition). New York, NY: Routledge. 